\title{
DO YOU CAPTURE FINANCIAL CRISIS?
}

\author{
Murniati Mukhlisin ${ }^{1}$ \\ Ratna Komalasari ${ }^{2}$
}

\begin{abstract}
This article summarizes the multitude of 330 empirical studies in the area of Islamic banking and finance with purpose to analyze impact of Islamic banking and finance studies to practice by mapping research direction and the depth of the study. The studies are categorized based on research paradigm, countries being researched, methods employed, and results that lead to policy direction in the particular period. The research found that the research direction of the papers under study mostly employ positivist paradigm with countries being researched are generally Malaysia, Pakistan, Indonesia, UAE and Saudi Arabia. It documents that the papers did not link directly to the future policy directions for instance to predict and prepare for financial crisis, rather they merely responded to the undergoing policies or themes of the journals. This review provides insights for understanding the importance of guiding future policy direction in the area of Islamic banking and finance by publishing more research policy papers authored by both academics and professionals.
\end{abstract}

Keywords: Meta Analysis, Islamic Banking, Islamic Finance, Financial Crisis

JEL Classification: M10, M16

Received: September 21, 2017; Revised: January 31, 2018 ;

Accepted: February 13, 2018

Tazkia University, College of Islamic Economics. Corresponding email: murniati@tazkia.ac.id

2 Researcher, Institute of Research and Community Empowerment Tazkia. 


\section{CONVENTIONAL AND ISLAMIC BANKING AND FINANCE CURRENT RESEARCH PAPERS}

Current research papers on conventional or Islamic banking and finance mostly employ quantitative analysis using statistical methods. During the past two decades from 1990 to 2009 most studies used regression analysis and positivist paradigm (Jang \& Park, 2010). As such, quantitative analysis is deemed appropriate to analyse secondary data that are conveniently obtained from online database such as Bankscope, Bloomberg, Mix Market, Zawya and handpick from annual reports. According to Kothari (2004), the purpose of conducting research is to find answers to research questions by applying scientific procedures to achieve new insights; to predict characteristics of a particular individual, situation or a group; to define the frequency of an event; and to test a hypothesis of variables. However, there are not many studies that could help the audience use the research output for their decision making process. This is due to several factors, such as the ability the researchers to relate their studies to the real problems. In other predicament, their research papers may be relevant for future direction but their research takes long time to publish. For Scopus journal for instance, the process could take one to three years and high impact journals would take one to seven years to publish. Obviously, after the publication, most data becomes absolute or merely a report.

The financial crisis in 2008 that hit Greek and the whole Europe was a shock to Queen Elizabeth, Her Majesty Queen of England(Guardian, 2012). The Queen questioned the academics and experts at London School of Economics (LSE) and Bank of England (BoE) why the crisis could happen. "Oh," she said, slightly taken aback, as Kapadia went on to explain that as the global economy boomed in the pre-crisis years, the City had got "complacent" and many thought regulation wasn't necessary. The Queen was unpleasant when knowing even the academics of LSE; a world ranking school of economics could not respond the real economic problems. This evidence is telling us that the academics at LSE and BoE were not able to predict the 2008 financial crisis. It went on to say for instance, Journal of Finance, in 2007 and 2009 (one year before and one year after the financial crisis) issued 152 research papers in 12 issues. Only three from the 152 research papers that discussed financial crisis although they were not directly on Greek where the crisis first started.

What about in the area of Islamic banking and finance research? This is what the research would like to investigate; do research papers on Islamic banking and finance inform decision makers to issue on-time policies to 
anticipate financial crisis? This research summarizes the multitude of empirical studies in the area of Islamic banking and finance with purpose to analyze impact of Islamic banking and finance studies to practice by mapping past research according to exogeneous and endogeneous factors suggested by Beaver (1996). The article proceeds as follows. Section 2 presents a discussion on research mapping studies, followed by Section 3 on theory of financial crisis and meta analysis method. While Section 4 maps Islamic banking and finance papers, Section 5 concludes the paper and provides recommendation for future research.

\section{STUDIES ON RESEARCH MAPPINGS}

Berger, Hunter \&Timme (1993) in Journal of Banking and Finance $\left(4^{*}\right)$ collect citational data over the ten-year period 1984 to 1993 from every issue of the Journal of International Business Studies. They found that management, economics, marketing, and finance disciplines have had significant influence on international business research and identified researchers such as Dunning, Porter, Vernon, Casson, Rugman, and Hofstede as having made significant contributions to international business research. Loe, Ferrell \& Mansfield (2000) in Journal of Business Ethics ( $3 *$ ) summarizes empirical studies that test ethical decision-making in business and suggests additional research necessary to further theory in this area. The studies are related to awareness, individual and organizational factors, intent, and the role of moral intensity in ethical decision making with purpose to provide insights for understanding organizational ethical decision constructs and future empirical work on organizational ethical decision making. In accounting research, similar work was conducted by Luft \& Shields (2003) in Accounting, Organization and Society $\left(4^{*}\right)$ that provides a summary graphic representation of the theory-consistent evidence about the causes and effects of management accounting. It summarizes 275 articles published in six leading journal that highlights connections and disconnects in the diverse streams of management accounting literature, in terms of what has been researched, the direction and shape of the explanatory links proposed, and the levels of analysis. Based on criteria from social-science research, the authors offer 17 guidelines to help future research capture natural connections, avoid artifactual connections, and develop a more complete and valid map of the causes and effects of management accounting.

In other management accounting research, Van der Stede, Young, $\&$ Chen (2005) in Accounting, Organization and Society $\left(4^{*}\right)$ address the 
quality of survey research in management accounting using framework containing the five key elements of a well-designed survey to assess the quality of all mail surveys in management accounting published in eight accounting journals over a 20-year period (1982-2001). Their analysis shows that over time survey research in management accounting has improved, however, more attention to improving the ways in which the survey method is deployed. Lastly, Beaver (1996) in Accounting Horizon (4*) affirms that Not so-Early Research (NEAR) and Future Accounting Research (FAR) are influenced by several factors among others exogeneous and endogeneous factors. From 25-years study, he concludes that factors such as data availability, environment, theory and academic research are significant.

The above papers are published in the highest ranking journals with focus on the area of finance and accounting. The studies are examined very thoroughly and the recommendation is helpful for decision-making process and research future direction. However, there is no evidence that shows a similar study conducted in the area of Islamic banking and finance. Aliyu et al. (2017) conduct a literature review on the Islamic banking sustainability but did not cover other Islamic financial institutions such as Islamic insurance, Islamic capital market and general finance.Therefore this is the motivation of the research that expands the coverage while at the same time focuses on the role of Islamic finance research to avoid financial crisis.

\section{THEORY ON FINANCIAL CRISIS AND META ANALYSIS}

Financial institutions have been facing a repetitive crisis in the recent decade, starting from the financial collapse due to the Great Depression ${ }^{3}$ in 1929, which was then revived through the Keynes and Minsky economic policy intervention (Crotty, 2009). However, the Keynes and Minsky theories were later replaced with more efficient financial market hypotheses. After the world faced the economic and financial turbulence of the 1970s and early 1980s, a new classical macro-economic theory arose, signifying a serious crisis of capital accumulation (Harvey, 2005). The tight financial regulations were justified by an efficient financial market theory, which then embarked on new globally-integrated deregulated neoliberal capitalism (Crotty, 2009). The financial formation began after the Great Depression in 1929 with Keynes and Minsky theories for economic recovery. The formation was stopped due to financial turbulence in 1970 s

\footnotetext{
${ }^{3}$ It was not just America but spread to Great Britain (known as Great Slum).
} 
and 1980s, which, through weakening the government supervisory mechanism, led to radical deregulation programs of financial institutions. The financial institutions were then blamed for the last two consecutive crises in 1997 and 2008. With incentive to accumulate profit, the financial institutions, particularly banks, were depicted like a financial bubble. A financial crisis first hit Thailand's currency (baht), which was heavily tied to the speculative property market in 1997. The crisis then spread to Indonesia, Malaysia and the Philippines, and later reached countries such as Hong Kong, Taiwan, Singapore and South Korea (Harvey, 2005, p. 96).

IFR (2009) documents the following long list of past financial crisis; 1. LatAm sovereign debt crisis - 1982; 2. Savings and loans crisis - 1980s; 3.Stock market crash - 1987; 4.Junk bond crash - 1989; 5. Tequila crisis 1994; 6.Asia crisis - 1997 to 1998; 7.Dotcom bubble - 1999 to 2000; and 8. Global financial crisis - 2007 to 2008. In 2008, a second financial crisis started due to the US sub-prime mortgage industry, which shook financial institutions in almost the entire world. The global banks exaggerated their balance sheet-asset from US $\$ 10$ trillion in 2000 to US $\$ 23$ trillion in 2006 due to the bank holdings of MBSs and CDOs. In 2009 IMF estimated potential losses banking practices on US-originated credit assets for US $\$ 2.7$ trillion in 2007-2010 (Crotty, 2009). It means the financial bubble had burst: there were no liquid assets in the balance sheet; it was merely creation of debts on top of debts. It definetly raises a question why researchers did not inform the policy makers so that they could make the right prediction?

Two conclusions can be derived from the crisis. First of all, it is clear that researchers have not been so helpful in making prediction to crisis. This is crucial because the crisis could diminish the welfare of the entire society, through last resorts methods such as government bailout (as was the case in Indonesia in 1997-1998 and Greece in 2007-2008). Secondly, similarly to United Kingdom in (2007-2008), poor policy research leads to weak government regulation, and thus the activities of the financial institutions in the country were not properly supervised. It is deeply worrying that United Kingdom, with its hundreds of years of experience in the financial industry and academic research, was not being able to foresee the crisis. It can be argued that perhaps people became a bit negligent because they are so used to living in a welfare state. The story of Prophet Yusuf, who advised the King of Egypt about anticipating "future risk' such as vulnerable conditions after a period of plentiful prosperity, may be relevant to this scenario (Qur'an Yūsuf (12), verse 43-49). 
Parashar and Venkatesh (2010) conclude that Islamic banks did suffer during crisis in terms of lowering of Capital Adequacy Ratio, Equity/Total Assets and Return on Average Equity although in some other years they tend to perform better than the conventional banks. In other research, Alqahtani, Mayes \& Brown (2016) argue that the Islamic banks performed better in terms of capitalisation, profitability and liquidity in the early stage of the global financial crisis. However, they perform worse in later stages with the real economic downturn. This is to show that although Islamic banking and financial institutions could be resilient from the crisis, but it is unfair to say that "they are too holy to fail or too big to fail." Looking at a specific need of Islamic banking and financial institutions, thus research on the area must be more informed and reliable.

\section{METHODOLOGY}

This research aims to prove whether research papers on Islamic banking and finance inform decision makers to make right decision that relates to prevention to financial crisis. The scope of this article covers research papers ranked in Academic Journal Guide, Association of Business School (ABS) 2015 version. The guide is specific on business school studies unlike Scopus List or Thomson \& Reuters that index and rank papers form various disciplines. The ABS rank journals through six steps such as; 1.Assessing the need of business and management research community; 2 . Ranking from $1-4^{*}$ (read: star/s) after consulting at least three out of five international journal listings; 3 . Classifying the journals through several reviews; 4.Drawing comprehensive coverage of research; 5 . Finalizing process from editors; and 6. Stating justification from editors on the methodology.

The method of this research is first, the authors list down 1-4* journals published in ABS under the "Finance" heading then search the subject with keywords: "Islamic banking and finance." There are 25 journals from 102 journals that have published papers on Islamic banking and finance including one Islamic finance journal (International Journal of Islamic and Middle Eastern Finance \& Management/IIMEFM), as follows:

1. Managerial Finance (MF), ${ }^{*}, 16$ papers

2. Applied Financial Economics (AFE), 2*, 6 papers

3. Journal of Banking Regulation (JBR), $2^{*}, 8$ papers

4. The Journal of Risk Finance (TJRF), 1* 6 papers 
5. Intl Journal of Islamic and Middle Eastern Finance \& Mgt (IJIMEFM), $1 *, 117$ papers

6. Qualitative Research in Financial Markets (QRFM), 1*, 26 papers

7. Journal of Banking \& Finance (JBF), $3 *, 5$ papers

8. Pacific-Basin Finance Journal (PBFJ), 2*, 18 papers

9. Journal of International Financial Management \& Accounting (JIFMA), 2*, 1 papers

10. International Journal of Managerial Finance (IJMF), $2 *, 2$ papers

11. Journal of Financial Stability (JFS), 3*, 2 papers

12. Research in International Business and Finance (RIBF), $2 *, 17$ papers

13. Review of Behavioral Finance (RBF), $1 *, 1$ paper

14. Journal of Financial Regulation and Compliance (JFRC), $1 *, 3$ papers

15. Corp Governance: The International Journal of Business in Society (TIJBS), 3*, 1 paper

16. Global Finance Journal (GFJ), 2*, 2 papers

17. Finance Research Letters (FRL), $2 *, 2$ papers

18. Applied Economics (AE), 2*, 6 papers

19. Review of Finance (RF), 4*, 1 papers

20. Journal of Multinational Financial Management (JMFM), 2*, 2 papers

21. Journal of Asset Management (JAM), 2*,4 papers

22. International Review of Financial Analysis (IRFA), 3*, 2 papers

23. Journal of Islamic Accounting and Business (JIABR), 1*, 71 Papers

24. The Geneva Papers on Risk (TGPR), 2*, 1 paper

25. The European Journal of Finance (TEJF), $3 *, 1$ paper

26. Finance Research Letters (FRL), $2 *, 2$ papers

27. Review of Finance (RF), 1*, 1 paper 
28. Corporate Governance: An International Review (CG), 3*, 2 papers

29. Financial Markets, Institutions and Instruments (FMII), 3* 2 papers

30. Physica: A Statistical Mechanics and its Applications (PSMA), 2*, 1 paper

31. Journal of Emerging Market Finance (JEMF), 2*, 1 paper

Second, the authors read and summarize the papers and group them into several constructs such as shown on Table 1 below; and third, the authors discuss the constructs and conclude. The method to map the research papers refers to Beaver (1996) that talks about exogenous and endogenous factors. Exogenous factos according to Beaver (1996) are application from other disciplines, data availability, environmental changes while endogeneous factors are influence from academic community (journals, conferences, and policies) and theory and evidence of the research.

As for data availability, it derives from 34 years of publications from 1983 to 2017 that show Islamic finance and banking environment in Malaysia, Pakistan, Indonesia, UAE, and Saudi Arabia as five major countries under study. It also highlights what theory and method employed by the researchers.

\section{MAPPING OF ISLAMIC BANKING AND FINANCE RESEARCH}

From 330 papers, the major issueslay on Islamic banking, Islamic capital market, Islamic insurance (takaful), general Islamic finance issues, unit trust fund, equity and endowment fund (waqf). Table 1 describes details of the mapping:

Table 1.

Number of empirical research papers in Islamic banking and finance

(1983-2017)

\begin{tabular}{ll}
\hline Construct & Number of empirical studies \\
\hline Focus & \\
Banking & 174 \\
Takaful & 13 \\
General Finance & 59 \\
Islamic Capital Market & 73 \\
Unit Trust Fund & 1 \\
Pension & 1 \\
Equity & 8 \\
\hline
\end{tabular}




\begin{tabular}{llll}
\hline Countries & & & \\
Malaysia & 96 & Algeria & 6 \\
Pakistan & 55 & Nigeria & 7 \\
Indonesia & 40 & United Kingdom & 12 \\
UAE & 37 & Syria & 6 \\
Saudi Arabia & 32 & Tunisia & 12 \\
Bahrain & 28 & Austrlia & 5 \\
Kuwait & 25 & South Africa & 5 \\
Qatar & 23 & Singapore & 5 \\
Bangladesh & 23 & Gambia & 5 \\
Turkey & 20 & OlC & 5 \\
Asia & 16 & Morocco & 5 \\
MENA & 21 & France & 4 \\
Iran & 15 & Switzerland & 4 \\
Sudan & 15 & Brunei Darussalam & 3 \\
United States & 15 & German & 3 \\
Jordan & 20 & Italy & 3 \\
Africa & 12 & Rusia & 3 \\
GCC Countries & 16 & Hongkong & 3 \\
Yemen & 12 & Sinegal & 3 \\
Egypt & 12 & Libya & 3 \\
Europe & 10 & Palestine & 4 \\
Middle East & 8 & Argentina & 2 \\
India & 8 & Brazil & 2 \\
Oman & 8 & South Korea & 2 \\
Canada & 7 & Swiss & 2 \\
Lebanon & 7 & & \\
Universal & 15 & & \\
\hline
\end{tabular}

The above table indicates academics have preference to Malaysia, Pakistan, Indonesia and UAE (above 30 papers) as opposed to Argentina, Brazil, South Korea, KSA and Swiss, which are among the least that are selected by the academics. The following table shows how the papers are analyzed that starts from focus area of study to country being researched, sample, method and research paradigm. From the findings, this research concludes whether they have correlation with the anticipation of financial crisis that occur few years before and/or after the publication.

These are the financial crisis occurred during the period; LatAm sovereign debt crisis - 1982; Savings and loans crisis - 1980s; Stock market crash - 1987; and Junk bond crash - 1989. The journals papers within this period did not discuss anything about the financial crisis and its impact on Islamic banking and finance although the financial crisis between 19971998 that hit South East Asia in particular Thailand and Indonesia brought worries to the future of Islamic banking and financial industry. The research 
theme and method are very much related to exogenous factors being the nature of journals.

1. LatAm sovereign debt crisis - 1982; Savings and loans crisis - 1980s; Stock market crash - 1987; Junk bond crash - 1989; Tequila crisis 1994; Asia crisis - 1997 to 1998

Although the first modern bank was established in 1963 (see 1983, Bashir: JBF, Appendix 1) Mit Ghamr Bank, Egypt), there was no evidence of any paper on Islamic banking and finance published ever since. The first paper was published twenty years after Mit Ghamr's inauguration in 1983 (see and after that there is a big jump from 1983 to 1999 that indicates that there was no relevant paper published in Finance-ABS group.

There are two huge financial crisis during this period i.e. Dotcom bubble - 1999 to 2000 and Global financial crisis - 2007 to 2008 and these papers did not touch the issue of financial crisis within the period or events that occurred before year 2000 (see Appendix 1). Only one paper by Satkunasingam \& Shanmgam (2004) analyzing risk exposure of Islamic banking that could be prevention to crisis. Managerial Finance with its quantitative characteristics has been dominating Islamic banking and finance publications from 1983 to 2005.

\section{Dotcom bubble - 1999 to 2000; Global financial crisis - 2007 to 2008}

From these papers, the researchers maintain the perception that Islamic banking and financial institutions are resilient and will continue performing. However Picture 1 below shows that Islamic banking and finance growth experienced severe downturn in 2009-2010 which could be an impact of the financial crisis 2007-2008. 


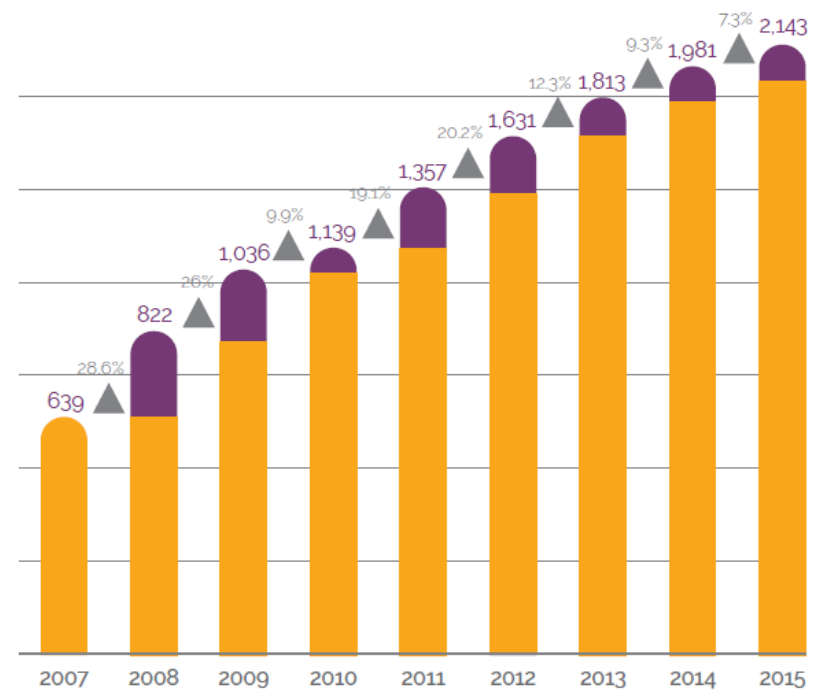

Source: GIFR, 2017

Figure 1.

Size and Growth of Islamic Banking and Finance between 2007-2015 (in billion USD)

The growh that was increased for $28.6 \%$ from 2007 to 2008 and $26 \%$ from 2008 to 2009, lowered down to $9.9 \%$ from $2009-2010$. The commendable growth during 2007-2008 was due to "60-70\% floating mass" that claimed by ATKearney (2012) where conventional customers "float" to Islamic banks. In response to the anticipation to crisis, some papers have indicated risks that the Islamic banking and financial institutions should adhere with, such as "Conventional and Islamic banking have differences level of risks" (Ariffin, Archer, Karim, 2008), Most important types of risk in Brunei is foreign-exchnge risk, credit risk and operating risk. However the discussion on the financial crisis in 2007-2008 was not thoroughly discussed. The endogenous factors such as the influence from academic community is quite dominant. In this case, research themes set by the journal editors of Managerial Finance and International Journal of Islamic and Middle Eastern Finance \& Management.

From Picture 1 above, the growth of Islamic banking and finance was not really significant which was from $19.1 \%$ to $20.2 \%$ from in $2011 / 2012$. It then declined to $12.3 \%$ in $2012-2013,9.3 \%$ in $2013-2014$, and $7.3 \%$ in 2014-2015. It seems that the issue of money laundering and terrorism financing became the main topic as reported by IFSB (2016) that could be a threat to Islamic banking and finance. However, there is no paper 
between 2011-2015 that discussed details about the money landering and terrorism. Only one paper under "General Finance" i.e. Ballard (2005) who discussed anti Money Laundring/Combat Finance Terrorism initiatives. There are 17 papers discussing about risks out of 74 papers above that could be the implication from 2008 financial crisis. However, the poin of discussion on the paper did not specifically mention the period of the crisis.

\section{When will the next financial crisis?}

S\&P Global Ratings states year 2017 will be another difficult year for Islamic finance (S\&P, 2017), which is confirmed by Sri Mulyani, Finance Minister, Republic of Indonesia. She argues that 2017-2018 would be 10-years on crisis, repeating crisis from 1997-1998 crisis and 2007-2008 crisis.

However, year 2016-2017 papers shows more variety in discussing risks and financial crisis for instance The Islamic banks performed better in terms of capitalisation, profitability and liquidity in the early stage of the global financal crisis, they performed worse in later stages with the real economic downturn. However, it seems that the researchers have conflicting views; Islamic banks seem to be less stable than their conventional peers versus Islamic banks are relatively better in profitability, efficiency, risk and liquidity management. Overall, the issues such as the crisis of refugees fleeing Iraq and Syria should actually offer a major challenge to Islamic banking and finance but no paper has discussed it. There are some papers that discussed the effect of financial crisis to Islamic banking and finance, such as The impact of the current crisis on the Islamic finance industry is less marked than on conventional finance; Islamic mutual funds generally outperformed conventional funds in the riskiest asset class, equity, one year before and during the global financial crisis.; and the Islamic indexes seem to be more risky than their conventional. However, papers on mitigating risk for future financial crisis is missing, see Appendix 3.

Some papers are concerned on the risk and financial crisis such as; Islamic stock markets are not immune to the global financial crisis, During major crisis the Islamic stock index is not less risky but also significantly different from conventional stock market; Islamic CAPM is appropriate and applicable in investigating the linkage among risk and return in the Islamic stock market. It is shown from the findings that the capital market research put more concerns on mitigating risk of financial crisis as compared to Islamic banking research. From 2013 to 2017, the general finance topics tend to discuss framework and disclosure of risk (see Appendix 3 and 4). 
This trend follows Islamic capital market topics presented in the previous table. However, there is no much discussion on anticipating financial crisis. Research in "Takaful" has not much addressed risks and financial crisis except on the paper that differentiates Islamic and conventional insurance demand. Overall, the papers are very much on strategy of developing Islamic insurance.

\section{CONCLUSION AND RECOMMENDATION FOR FUTURE RESEARCH}

\subsection{Conclusion}

After examining the 330 papers from 31 high ranking journals, the answer to the research question "Do research papers on Islamic banking and finance inform decision makers to issue on-time policies to anticipate financial crisis?" are as follows:

a. There are four major classification of studies from 330 papers within the period of 1983-2017, namely: Islamic banking, Islamic capital market, general Islamic finance issues, Islamic unit trust fund, Islamic insurance (takafu), with main focus on four countries; Malaysia (79 articles), Pakistan (46 articles), Indonesia (37 articles), UAE (34 articles), and Saudi Arabia (32 articles). This is quite interesting to find that Iran is not the focus although Iran has been ranked as number one country with the highest Islamic banking and finance growth (see GIFR, 2016). Iran in this study is recorded in 15 articles only. In the early years, the journal that published the highest number of Islamic banking and finance articles was Managerial Finance (19 articles) followed by Applied Economics (44 articles). In the later years, International Journal of Islamic and Middle Eastern Finance and Management published the highest number of articles (106 articles) followed by Journal of Islamic Accounting and Business Research (71 articles).

b. The papers under study are not timely to respond to the problems in reality, which are seen from number of papers that merely responded to what has happened. It is shown from the number of financial crises that are not predicted in the Islamic banking and finance studies.

c. Researchers have been so overwhelming in praising the growth of Islamic banking and finance Islamic banking and financial institutions, such as: "Islamic banking has made unprecedented progress over recent years" (Khan \& Bhatti, 2008); "Foreign Islamic banks, on average, follow aggressive financing in host countries and enjoy 
higher net profit margin" (Hassan, Sanchez \& Safa, 2013). The research papers are not tally with growth trend in 2012 that has been slowing down till 2015 or did not predict as what has been stated by S\&P Global Ratings that states year 2017 will be another difficult year for Islamic finance (S\&P, 2017).

As proposed by Beaver (1996) exogeneous and endogenous factors are discussed in this study and found significant. Themes set by conference organizers and journal editors affect direction of theory and pattern in academic research. The caveat is on data availabity for 23 years from 1984 to 2017 only from ABS ranking journals.

\subsection{Recommendation for future research}

It is clear that Kothari (2004) highlights the purpose of research which is to "to portray accurately the characteristics of a particular individual, situation or a group" that means the Islamic banking and finance research in the future should be "contribution" oriented that would benefit the development of and eventually to the sustainability of Islamic Islamic banking and financial institutions. Secondly, in terms of research methodology there should be more critical thinking adopted in the studies to ensure the adherence to Shariah is fulfilled, not only for pro-growth per se. Thirdly, this review motivates the researchers to publish high quality research policy papers authored by both academics and professionals with purpose to reduce gaps between theory and practice. Finally, from several events that have been happening, there is a need to conduct risk based research to anticipate future trubulence in the Islamic banking and finance industry. 


\section{REFERENCES}

Aliyu, S., Hassan, M.K., Yusof, R.M., \&Naiimi, N. (2017). Islamic Banking Sustainability: A Review of Literature and Directions for Future Research. Emerging Markets Finance and Trade, 53(2).

Berger, A. N., Hunter, W. C., \& Timme, S. G. (1993). The efficiency of financial institutions: A review and preview of research past, present and future. Journal of Banking \& Finance, 17(2), 221249.

Beaver, William H. (1996). Directions in accounting research: NEAR and FAR. Accounting Horizons; Jun 1996; 10, 2; ABI/INFORM Global, 113

GIFR. (2017). Size and Growth of Islamic Banking and Finance between 2007-2015, Global Islamic Finance Report. BMB Islamic UK Limited: London.

Crotty, J. (2009). Structural Causes of the Global Financial Crisis: a Critical Assessment of the 'New Financial Architecture'. Cambridge Journal of Economics, 33, 563-580.

GUARDIAN. (2012). Queen Finally Finds out Why No one Saw the Financial Crisis Coming [Online]. Retrieved from http://www.theguardian.com/uk/2012/dec/13/queen-financial-crisisquestion (Accessed on 23 March 2014).

Harvey, D. (2005). A Brief History of Neoliberalism, New York, USA, Oxford University Press.

IFSB. (2016). Sustainability Report, 2016, Retrieved 20 September 2016, from https://www.islamicfinance.com/wpcontent/uploads/2016/06/IFSI-Stability-Report-2016-final.pdfIFSIStability-Report- 2016- final.pdf.

Jang, S., \& Park, K. (2011). Hospitality finance research during recent two decades: subjects, methodologies, and citations. International Journal of Contemporary Hospitality Management, 23(4), 479-497.

Mulyani, S.. (2017). Menakar Potensi Terjadinya Krisis Keuangan 10 Tahunan di 2018. News Retrived on 16 February 2018, from http://ekonomi.kompas.com/read/2017/11/06/080000426/menakar -potensi-terjadinya- krisis-keuangan-10-tahunan-di-2018. 
Luft, J., \& Shields, M. D. (2003). Mapping management accounting: graphics and guidelines for theory-consistent empirical research. Accounting, Organizations and Society, 28(2), 169-249.

Loe, T. W., Ferrell, L., \& Mansfield, P. (2000). A review of empirical studies assessing ethical decision making in business. Journal of Business Ethics, 25(3), 185-204.

Parashar, S.P. \& Venkatesh. (2010). How did Islamic banks do during global financial crisis? Banks and Bank Systems, 5(4).

S\&P. (2017). Islamic Finance Outlook 2017 Edition, Retrieved 21 September 2017, from https://www.spratings.com/documents/20184/0//slamic+Finance+O utlook+2017/5abbe572-c826-4622-bd13-1aba725281fc

Van Der Stede, W. A., Young, S. M., \& Chen, C. X. (2005). Assessing the quality of evidence in empirical management accounting research: The case of survey studies. Accounting, Organizations and Society, 30(7), 655-684.

IFR. (2009). International Financial Review: A history of the past 40 years in financial crises. Retrieved from http://www. ifre.com/a-history-of-thepast-40-years-in-financial crises/21102949. fullarticle

Note: 330 references are not included in the reference list for conviniences purposes, data will be supplied by the auhors upon request. 


\section{APPENDIX}

Table 1.

Empirical research papers in Islamic banking and finance (1983-1999)

\begin{tabular}{|c|c|c|}
\hline Yr/Author:Journal & $\begin{array}{c}\text { Country, Sample, Method, } \\
\text { Paradigm }\end{array}$ & Findings \\
\hline 1983, Bashir: JBF & $\begin{array}{l}\text { Sudan, 1978-1980 current \& saving } \\
\text { account , Mathematical approach, } \\
\text { Poststructurialism }\end{array}$ & $\begin{array}{l}\text { Initial attempt to develop a } \\
\text { simple mode for the portfolio } \\
\text { management of an Islamic } \\
\text { bank. }\end{array}$ \\
\hline $\begin{array}{l}\text { 1995, Prodhan \& } \\
\text { Khan: AFE }\end{array}$ & $\begin{array}{l}\text { Pakistan, 72: shares listed on KSE } \\
\text { 1982-9t, Regression, Positivism }\end{array}$ & $\begin{array}{l}\text { Impact on securities prices of } \\
\text { Pakistan's move towards full } \\
\text { Islamization in the financial } \\
\text { sector. }\end{array}$ \\
\hline
\end{tabular}

Table 2.

Empirical research papers in Islamic banking and finance (1999-2005)

\begin{tabular}{|c|c|c|}
\hline Yr/Author:Journal & $\begin{array}{l}\text { Country, Sample, Method, } \\
\text { Paradigm }\end{array}$ & Findings \\
\hline 1999, Loqman: MF & $\begin{array}{l}\text { Asia, Europe and Africa, } \\
\text { Comparative and analytical } \\
\text { methods, Interpretivism }\end{array}$ & $\begin{array}{l}\text { Islamic banks and financial } \\
\text { institutions should demonstrate } \\
\text { their viability for the western } \\
\text { world to cooperate with them. } \\
\text { Islamic bank's choice of } \\
\text { financing instruments is not } \\
\text { consistent with profit-loss- } \\
\text { sharing principle. }\end{array}$ \\
\hline $\begin{array}{l}\text { 2001, Choudhury \& } \\
\text { Al-Hallaf: MF }\end{array}$ & $\begin{array}{l}\text { Saudi Arabia, Self-referencing } \\
\text { methodology and the IIE-model, } \\
\text { Positivism }\end{array}$ & $\begin{array}{l}\text { Interactive financial index could } \\
\text { not be achieved as it contrasts } \\
\text { the Islamic approach. }\end{array}$ \\
\hline 2003, Harahap: MF & $\begin{array}{l}\text { Indonesia, Comparative and } \\
\text { analytical methods, Interpretivism }\end{array}$ & $\begin{array}{l}\text { The current disclosure system } \\
\text { gives no indication of justness or } \\
\text { fairness it is incompatible with } \\
\text { Islamic values. }\end{array}$ \\
\hline $\begin{array}{l}\text { 2003, Schramm \& } \\
\text { Taube: IRFA }\end{array}$ & Literature review, Interpretivism & $\begin{array}{l}\text { Hawala system plays a central } \\
\text { role in the shadow economy } \\
\text { throughout the world. }\end{array}$ \\
\hline
\end{tabular}


2003, Makiyan: MF

2004, Satkunasingam \& Shanmgam, JIBR

2004, Muljawan, Dar \& Hall: AFE

2005, Ballard: JBR

2007, Abdullah, Hassan \& Mohamad: MF

2008, Yusof \& Majid: IJIMEFM

2008, Al-Zoubi, Maghyereh, Al-Zu'bi \& Bhatti: MF

2008, Jobts, Kunzel, Mils \& Sy: IJIMEFM

2008, Rosly \& Zaini: MF

2008, Haron \& Azmi: MF

2008, Siddiqui: MF

2008, Ariffin, Archer, Karim: JBR
Iran, 11 Period (1984-1994):

Average RoR, Total deposits in The government intervention banks, Rate of inflation, Error plays more important role of Correction Model (ECM), Positivism economic factors.

Malaysia, Literature review, Interpretivism

Critical

Poststructurialism

thinking,

Greater risk disclosure leads the patrons of Islamic banking to realise the extent of their risk exposure.

Higher financial participation and higher quality of information will improve the quality of the banks and their customers.

Informal Value Transfer System reinforced Anti Money Laundring/Combat Finance Terrorism initiatives.

Islamic funds performed better than the conventional funds durng bearish economic trends.

Thesecurities is the most significant market in attracting Foreign Portfolio Investment into the economy.

General equilibrium model, Positivism

The constructing a zakah fund can take the role of issuing debt in financial market.

Malaysia, Paper review, Interpretivism

Sukuk market continues to generate strong interest by new issues.

Deposit yields in conventional Malaysia, 13: RoE, ROMD, banks were lower than ROE and Financial ratio approach, Islamic banks' deposit yield and Positivism ROEs do not reflect their risktaking properties.

Differenct determinants on deposits at both Islamic and conventional banking systems.

Islamic Banks tend to engage in little long-term project financing.

Conventional and Islamic banking have differences level of risks. 
2008, Khan \& Bhatti: MF

2008, Khan \& Bhatti: TJRF

2008, Benamraoui: IJIMEFM

2008, Dusuki: IJIMEFM

2008, Hasan: IJIMEFM

2008, Amin \& Isa: IJIMEFM

2008, Obiyo: IJIMEFM

2008, Bacha: IJIMEFM

2008, Fauziah, Taib, Ramayah \& Razak: IJIMEFM
Middle East, South East and South East Asia, General review, Interpretivism

Middle East, South Asia and Indian Subcontinent, General review, Interpretivism

Algeria, 18: Senior managers from banque Al-Baraka d'Algerie, Interview, statistical data and financial ratio, Interpretivism

Malaysia, 1500: representing seven stakeholder groups, namely customers, depositors, local communities, Islamic banking managers, employees, banking regulatory officers and sharia advisers, Factor analysis, Positivism

Malaysia, Literature Review, Interpretivism

Malaysia, 440: Questionnaires distributed to two banks, Structural equation model (SEM), Positivism

Nigeria, Literature Review, Positivism

Malaysia, 9: Annually data for money market data from October 1998 to April 2007, Correlation \& regression, Positivism

Malaysia, 300: Post graduate students, Correlation \& regression, Positivism
Islamic banking and finance industry has become an alternative to conventional systems at the global level.

Islamic banking has made unprecedented progress over recent years.

Most of the Islamic financial products are short-term financing, the bank performance has improved.

Institution should uphold social objectives and promote Islamic value towards their staffs, clients and the general public.

Central banks will have to design new tools for credit control for Islamic banks.

High Muslim customers' awareness of the Islamic banking products and services.

Implementation and success of Islamic banking in Nigeria would require: re-shaping the society, restructuring of the economic system and re-framing of the laws according to the dictates of Islam.

Many of risks associated with conventional money markets, including interest-rate risks.

Diminishing Partnership (DP) concept and religious and social influence are jointly responsible. 


$\begin{array}{lll}\text { 2008, Rosly \& Zaini: } & \begin{array}{l}\text { Malaysia, 13: RoE, ROMD, } \\ \text { MF }\end{array} & \begin{array}{l}\text { Deposit yields in conventional } \\ \text { bositivism }\end{array}\end{array}$

Table 3.

Empirical research papers in Islamic banking and finance (After 2008)

\begin{tabular}{|c|c|c|}
\hline Yr/Author:Journal & $\begin{array}{c}\text { Country, Sample, Method, } \\
\text { Paradigm }\end{array}$ & Findings \\
\hline $\begin{array}{l}\text { 2009, Archer \& } \\
\text { Karim: JBR }\end{array}$ & $\begin{array}{ll}\text { Literature } & \text { review, } \\
\text { Poststructurialism } & \end{array}$ & $\begin{array}{l}\text { Profit-sharing investment account } \\
\text { holders is an equity investor } \\
\text { without the governance rights of } \\
\text { either creditors or shareholders. }\end{array}$ \\
\hline $\begin{array}{l}\text { 2009, Sufian \& } \\
\text { Noor: IJIMEFM }\end{array}$ & $\begin{array}{l}\text { MENA \& Asian countries, } \\
\text { Data Envelopment Analysis } \\
\text { (DEA), Positivism }\end{array}$ & $\begin{array}{l}\text { More efficient banks with smaller } \\
\text { market share and low non- } \\
\text { performing loans ratio. }\end{array}$ \\
\hline 2009, Hassan: TJRF & $\begin{array}{l}\text { Brunei Darussalam, Method } \\
\text { of Rl and risk facing the } \\
\text { sample banks, Positivism }\end{array}$ & $\begin{array}{l}\text { Most important types of risk in } \\
\text { Brunei are foreign-exchange } \\
\text { risk, credit risk and operating } \\
\text { risk. }\end{array}$ \\
\hline $\begin{array}{l}\text { 2009, Hassan, } \\
\text { Mohamad \& Bader, } \\
\text { IJIMEFM }\end{array}$ & $\begin{array}{l}\text { Middle East, 40: } 11 \text { OIC } \\
\text { Banks, Data Envelopment } \\
\text { Analysis (DEA), Positivism }\end{array}$ & $\begin{array}{l}\text { There is no difference between } \\
\text { the overall efficiency of } \\
\text { conventional and Islamic banks. }\end{array}$ \\
\hline $\begin{array}{l}\text { 2009, Amin, Hamid, } \\
\text { Lada \& Baba: } \\
\text { IJIMEFM }\end{array}$ & $\begin{array}{l}\text { Malaysia, 250: Bank } \\
\text { customers, Frequency, factor } \\
\text { and cluster analyses, } \\
\text { Positivism }\end{array}$ & $\begin{array}{l}\text { Bank customers are divided into } \\
\text { three clusters. }\end{array}$ \\
\hline $\begin{array}{l}\text { 2009, Derigs \& } \\
\text { Marzban: JBF }\end{array}$ & $\begin{array}{l}\text { Portfolio optimalization, } \\
\text { Poststructurialism }\end{array}$ & $\begin{array}{l}\text { On the same asset universe } \\
\text { current basic Shariah-compliance } \\
\text { strategie result is much lower } \\
\text { portfolio performance than } \\
\text { portfolios without considering } \\
\text { Shariah-compliance. }\end{array}$ \\
\hline $\begin{array}{l}\text { 2009, Kordvani: } \\
\text { IJIMEFM }\end{array}$ & $\begin{array}{l}\text { Iran, General review, } \\
\text { Interpretivism }\end{array}$ & $\begin{array}{l}\text { Increasing the level of efficiency } \\
\text { of the banking and financial } \\
\text { sector. }\end{array}$ \\
\hline $\begin{array}{l}\text { 2009, Ahmad \& } \\
\text { Hassan, IJIMEFM }\end{array}$ & $\begin{array}{l}\text { Australia, Mixture of direct } \\
\text { observation from legal and } \\
\text { regulatory perspective, } \\
\text { Emancipates }\end{array}$ & $\begin{array}{l}\text { Islamic financial services provides } \\
\text { nor conventional financial } \\
\text { institutions are disadvantaged. }\end{array}$ \\
\hline
\end{tabular}


2009, Alexakis \&

Tsikouras: IJIMEFM

2010, Rosly:

IJIMEFM

2010, Smolo \&

Mirakhor: IJIMEFM

2010, Karim, Kassim

\& Arip: IJIMEFM

2010, Ahmed:

IJIMEFM

2010, Kassim \&

Majid: IJIMEFM

2010, Ismal:

IJIMEFM

2010, Rahman,

Yahya \& Nasir:

IJIMEFM

2010, Mansour, Abdelhamid, Masood \& Niazi

2010, Kamil, Abdullah, Shahimi \& Ismail: IJIMEFM

General review
Interpretivism

Literature

Poststructurialism

Literature

Interpretivism

5 countries, Time series data from february 2006 to december 2008, Time series of cointegration, Positivism

Critical thinking, Critical orientation

Malaysia, 3: Three subperiods. Crisis(1997-1999), the non crisis (1999-2007) \& Crisis (2007-2009), VAR, Positivism

Indonesia, 3: Returns of group Islamic bank financing, VAR, Positivism

Malaysia, 642: Companiew listed on the Bursa Malaysia in 2006, Explanatory and descriptive in nature, Positivism

United Kingdom, 156: Statistical study, Positivism

Malaysia, Descriptive, analytical \& comparative analyses, Interpretivism
Growth of the Islamic finance sector may be impacted by the involvement inlslamic finance by western regulators, credit rating agencies; accounting procedures, protection of stakeholders.

Four approaches must be applied in package in determining Shariah compliant status to avoid costly errors.

Although the crisis had limited impact on Islamic financial institutions, the major flaws of capitalist financial system are relevant to the development of the institutions.

No evidence was found of cointegration among the Islamic stock markets in both periods.

A new business model for the banking system based on noninterest-based transactions but profit and loss sharing should be in pracice at the financial system.

Both the Islamic and conventional banking system are vulnerable to financial shocks.

Equity and debt-based financing produce suistainable returns of bank financing. The performance of service-based financing is very sensitive to the economic conditions.

Kuala Lumpur Stock Exchange Shariah Index does not use both the criteria set by the Dow Jones Islamic Market as its measures during the screning process.

Low services charges is top customers' criteria.

Sukuk have significantly different underlying structures, provisions a shariah-compliant. 
2010, Chazi \& Syed, IJIMEFM

2010, Norma, Majid, Kassim, Hamid and Yusof: IJMF

2010, Hassan \& Harahap: IJIMEFM

2010, Ismal: IJIMEFM

2010, Taktak, Zouari \& Boudriga: JIABR

2010, Haniffa \& Hudaib: JIABR

2010, Maali \& Napier: JIABR

2010, Maurer: JIABR

2010, Archer, Karim \& Sundararajan: JIABR
27: Capital ratios, Positivism

Malaysia, 5: Islamic unit truts companies , Data Envelopment Analysis (DEA), Positivism

7 countries, 7 Banks, Content analysis, Positivism

Liquidity risk management (LRM), Postivism

Various Muslim countries, 156: Islamic banks: Regression

Universal, Islamic \& Conventional banks: Literature Interpretivism review,

Jordan, Jordan national bank, Descriptive and literature review, interpretivism

Universal, Sukuk, Literature review \& descriptive, Interpretivism

Bahrain \& Dubai, Islamic banks, descriptive \& empirical research, Interpretivism

\section{Islamic banks are maintaining better capital ratios than their conventional counterparts.}

The efficiency of unit trust companies perform better than their conventional counterparts

CSR is not of major concern for most Islamic banks.

The index produces a good grade for the liquidity management practices in the Indonesian Islamic banking industry.

The results provide evidence on an extensive use of income smoothing by Islamic banks.

The sacred intentions to help Muslims fulfill their religious economic obligations especially with regards to riba (usury) have been distorted with secular goals as a result of the intervention of political-economic and social events

The paper shows that creating a new type of organisation - an Islamic bank - in Jordan required special legislation.

The role of sukuk in neoliberal reform and the privatization of state resources reveal a deeper potential conflict between Islamic standard-setting bodies and global neoliberal projects more broadly.

Characteristics of profit-sharing investment accounts can vary from being a deposit, displaced commercial risk (DCR) has a major impact on Islamic bank's economic and regulatory capital requirements, asset-liability management, and product pricing. 
2010, Lewis: JIABR

2010, Kader, Adams

\& Hardwick: TGP

2010, Hutapea \&

Kasri, IJIMEFM

2012, Ul-Haq: JIABR

2012, Ghauri \&

Qambar: QRFM

2012, Rehman:

QRMFM

2012, Alam \& Tang: QRFM

2012, Mirza \& Riaz: QRFM

2012, Rehman \& Masood: QRFM

2012, Akbar, Shah

\& Kalmadi: IJIMEFM

2012, Ahmad \&

Rahman: IJIMEFM

2012, Akhter \&

Hussain: IJIMEFM

2012, Hussain \& AlAjmi: TJRF
Malaysia, 149: Sharia-

compliant, Conceptual

framework, Interpretivism

7 countries, 26: Takaful non-

life insurance, Data envelopment analysis (DEA), Positivism

Indonesia, 5: two Islamic banks and three conventional banks , Autoregressive distributed lag model, Positivism

Universal, Literature review, Interpretivism

7 countries, 87: Bank in seven countries, BS, BM to total assets \& ROA, Positivism

3 countries, 225: Customers of Islamic banks, Regression, Positivism

14 countries, 99: Islamic banks , Prospect theory, Positivism

Pakistan, 100: Banks' employees, Cross-section, Positivism

Pakistan, 200: Islamic banking customers,

Regression, Positivism

United Kingdom, 156: Online respondents, PLS, Positivism

Malaysia, 10: Bank in Malaysia, Data Envelopment Analysis (DEA), Positivism

Pakistan, 150: Insurance customers, Chi-square test, Positivism

Bahrain, 560: Students in the Islamic finance course, URRM, RI, RAA, RMON, RMPs, CRA, Positivism
Islamic investment funds have grown rapidly this decade

Non-executive directors and separating the chief executif officer and chairman function do not improve cost efficiency.

Long-running relationship exists between the Islamic banking and its determinants.

The Islamisation model is not wholly appropriate in the banking sector.

Islamic banks reflect marginal bank spread but bear high operational costs.

Pakistiani \& UK customers consider assurance, reliability and empathy.

Islamic banks locate above target risk level tend to show risk-adverse behaviour.

Process of needs assessment identifies more than one training.

Religious and convenient factors are the most important factorain selecting an Islamic bank.

Islamic banking in the UK is not fully aligned with the Islamic finance paradigm.

Conventional banks may be more efficient than Islamic banks due to managerial efficiency and technological advancement.

Reporting standards and internal controls have low level of obsevance among Takaful operators in Pakistan.

The level of risks faced by Islamic banks are higher than conventional banks. 
2012, Ismal: IJIMEFM

2012, Yahya, Muhammad \& Hadi: IJIMEFM

2012, Khalid \& Amjad: TJRF

2012, Beck, Kunt \& Merrouche: JBF

2012, Garas: IJIMEFM

2012, Garas: IJIMEFM

2012, Kayed: IJIMEFM

2013, Alkhamess: JBR

2013, Laldin \& Furqani: IJIMEFM
Indonesia, Revenue sharing ratio, mathematical approach \& formula, Positivism

Malaysia, 3: Banks annual reports the year 2006 to 2008, Data Envelopment Analysis (DEA), Positivism

Pakistan, 135: Senior staff of head office, Regression, Positivism

22 countries, 209: Listed banks , Univariate comparisons, Positivism

Gulf Cooperation Council, 219: SSB member, Regression, Positivism

Ordinary least square regression, Positivism

Existing literature \& Critical analysis, Poststructurialism

Laws \& regulation analysis, Interpretivism

Literature Interpretivism
Equilibrium of revenue sharing ratio locates Islamic banks with no withdrawal risk and bankruptcy risk.

No significant difference in efficiency between Islamic banks and conventional banks.

Islamic banks are efficient in managing risk where understanding risk management, risk monitoring and credit risk management are the most influencing variables in risk management practices.

Islamic banks are less costeffective, but have a higher intermediation ratio, higher asset quality and are better capitalized. Ex-ante Shariah audit, ex-post Sharia audit and reporting of Shariah Control Drawing are related to the Shariah Supervisory Board (SSB) control.

SSB executive position, the relation between the SSB members and the BoDs, and the membership in Islamic funds and issuers of Islamic bonds are related to the conflicts of interest.

Visible shortage in practical research pertaining to the application of the principles of PLS modes in financing enterpreneurial activities.

Seven issues have been identified as main factors responsible for reducing the level of Shariah compliance in Islamic Financial Service.

Three specific ends (maqashid) in Islamic finance, namely wealth circulation, fair and effectively financial practices and justice at the micro-and macro-level. 
2013, Bannet \& Iqbal: IJIMEFM

2013, Ashraf: IJIMEFM

2013, Azmat, Skully \& Brown: PBFJ

2013, Ho, Rahman, Yusuf \& Zamzamin: PBFJ

2013, Quttainah, Song \& Wu: JIFMA

2013, Azzam \& Rettab: AE

2013, Hamza:

IJIMEFM

2013, Abedifar, Molyneux \& Tarazi: RF

2013, Mobarek \& Kalonov: $A E$
Comparative Interpretivism

method,

Islamic finance has grown at a very impressive rate over the last two decades but the Islamic fixed income market remains under-developed.

UAE, 159: Mutual funds listed on the Saudi Arabia stock market from 2007-2011, CAPM regression \& Treynor and Mazuy models, Positivism

Literature review, Positvism

8 countries, Period from 2000 to 2011 monthly closing value, Empirical method, Positivism

15 countries, 164: Islamic banks, Regression, Positivism

GCC countries, 55: Conventional banks 30 Islamic banks 25, Nonlinear regression, Positivism

Malaysia, Decentralized model in the Gulf Cooperation Council (GCC) \& Centralized model, Interpretivism

24 countries, 553: Banks over 24 countries, Compares the risk features, Positivism

OIC countries, 1857: Financial statemets, Data Envelopment Analysis (DEA) \& Stochastic frontier analysis (SFA), Positivism
Better performance of International Monetary Funds relative to conventional funds during periods of economic crisis.

The Islamic bond industry's existence is contingent upon a Shariah conscious ethical investor base that can absorb the lower sharia premium.

Islamic indices beat their conventional counterparts during show inconclusive for the non-crisis periods.

Nonegative different earnings management behaviors in Islamic banks, with and without Shariah Supervisory Boards.

The effect of concentration on margins is the sum of market power, marginal cost of intermediation and marginal cost of uncertainty.

The independence of the Shariah Board and the consistency of Shariah ruling are the principal components of Shariah governance structure.

Small Islamic banks appear more stable and loan quality of Islamic banks is less responsive to domestic interet rates.

Conventional banks are more efficient than their Islamic counterparts. 
2013, Hassan, Sanchez \& Safa: IJIMEFM

2013, Eljelly \&

Elobeed: IJIMEFM

2013, Amirzadeh \&

Shoovarzy: IJIMEFM

2013, Shafique, Hussain \& Hassan: TJRF

2013, Sukmana \& Kholid: QRFM

2013, Yusof \& Bahlous: JIABR

2013, Sherif \& Shaairi: JIABR

2013, Sarea \& Hanefah: JIABR

2013, Abdullah, Percy \& Stewart: JIABR

2013, Naim, Isa \& Hamid: JIABR
OIC countries, 24: Islamic Foreign Islamic banks follow bank financial statements, aggressive financing in host Weight least squares, countries and enjoy higher net Positivism

profit margin.

Liquidity risk, coverage, efficiency, profitability, capital adequacy \& control explain most of the variation of financial ratios.

Islamic doctrines and accessible Iran, 382: bank branches, brances are the least significant Fuzzy set theory, Positivism factors of service quality by Iranian bank customers.

Pakistan, 69: Financial The overall risk management institutions in Pakistan, practices of IFI and CFI are alike ANOVA-Test, Positivism in Pakistan.

Indonesia, Critical \& policies analysis, Critical orientation

Islamic banks are designed to boost the real sector, compared to conventional banks.

Islamic banking is found to GCC and East Asia, 13 lbs, contribute to economic growth VDCs, Positivism both in the long run and the short run

Malaysia, Malaysian annual data: 1986-2010, OLS \& Generalised method of moments, Positivism

Income, Islamic banking development, education, dependency ratio and Muslim population factors are positively related to Takaful demand.

Universal, Banks in Kingdom of Bahrain, Literature \& Descriptive analysis, Interpretivism

AAOIFI accounting standards can be made mandatory in all Muslim countries.

Shari'ah Supervisory BoardIndonesia \& Malaysia, Ibs: 23, related and zakat disclosures are Cross-sectional analysis, still limited, with only four banks Positivism

disclosing more than half of the SSB Index.

There were negligible changes on the principle term and condition (PTC) of the Sukuk after the Universal, Literature review, pronouncement, thus it did not Interpretivism have much effect in changing the Shariah Advisors and industry players when deciding more authentic principles and decisions. 
2013, Ismal \&

Haryati: QRFM

2013, Maturi:

IJIMEFM

2014, Kader,

Adams, Hardwick \&

Kwon: IRFA

2014, Baele, Farooq

\& Ongena: JBF

2014, Bahlous \&

Yusof: MF

2014, Faroog \&

Reza: IJIMEFM

2014, Nasr, Ajmi \&

Gupta: AFE

2014, Kok

Giorgioni \& Laws:

IJIMEFM

2014, Gupta, Hammoudeh, Kegne \& Sarafrazi: AFE

2014, Aloui, Hammoudeh \& Hamida: JIFMIM
December 2000-September 2010: monthly data of total assets of both Islamic \& financial asset, ARIMA models, Positivism

United Kingdom, 230: Online respondents , Analyzed statistically, Positivism

17 countries, 180: firm/years, Data Envelopment Analysis (DEA), Positivism

Pakistan, 150000: loans data set, The hazard function in duration analysis, Positivism

MENA countries, 260: Islamic equity funs, ARDL, Positivism

United States, 3: Market indices, Comparative study, Interpretivism

United States, Data span the period 1 january 1996-22 July 2013, fractionally integrated time-varying GARCH (FITVGARCH) model, Positivism

Combine and examining method, Poststructurialism

US, 16: Time period from 1997-2013, Regression, Positivism

GCC countries, 1241: Global GCC markets, Wavelet coherence analysis, Positivism
The optimum growth rate of the market share is predicted to occur in 2012 but slowing in October 2018.

The online respondents are likely to using takaful if the cover is offered as conventional insurance and the price are competitive.

Average levels of cost efficiency in takaful insurance markets mirror the efficiency in developed nonlife insurance markets.

Default rate in Islamic loans is less than half the default rate of conventional loans.

The international diversification can help reduce risk if Asia Pacific/ North America/ Europe funds and MENA region invested contemporaneously.

Performance based Islamic Market US can be improved when Technical Analysis is applied.

Terms of model diagnostics and information criteria as well as portfolio allocation.

Idea on Hybrid risk-sharing options by combining elements of both wa'ad and murabaha.

Dow Jones Islamic Market return is best predicted by an autocorrelation.

Sharia stocks and sukuk do not seem to behave differently from their conventional stock. The finding implies investors should consider simultanceously the short and long-run comovements. 
2014, Baki \&

Sciabolazza: QRFM

2014, Ginena: CG

2014, Muneeza \& Hassan: CG

2014, Aldohni: JBR

2014, Mohamad \& Rahman: IJIMEFM

2014, Suzuki \&

Uddin: IJIMEFM

2014, Ringim:

IJIMEFM

2014, Mokni, Echchabi, Azouizi \& Rachdi: JIABR

2014, Farooq: JIABR

2014, Echchabi, Olorogun \& Azouzi: JIABR

2014, Hamza \& Kachtouli: JIABR
North Africa \& Asia, 78: Financial data from 72 banks, Regression, Positivism

Literature Interpretivism

Explanatory and descriptive in nature, Poststructurialism

United Kingdom, Laws and regulation analysis \& literature review, Interpretivism

Literature

Interpretivism

Bangladesh,Bank rent theory \& empirical evidence, Poststructurialism

Nigeria, 286: Account holders, Pooled Least Square (PLS) model, Positivism

MENA, Ibs: 23, Perceptions of Islamic bankers, Interpretivism

MENA Country, firm: 20052009, post-recommendation market-adjusted returns, positivism

Tunisia, Tunisian customers: 1000, SEM, Positivism

MENA \& Southest Asia
region, Islamic and
conventional baks: 2004-
2009 , measure of the
competition and market
power, Positivism

The result show a consistent positive relationship between $C G$ and financial performance metrics.

This study concludes some risks that might appear in Islamic banks ie. Shariah, credit, compliance, market and reputation risks.

Code for Shariah corporate governance is needed due to the widespread.

The sharia compliance requirement has implication on the nature of Islamic banking operations.

Most of the studies discussed the fundamental theoriesinjurisprudence.

The asset-based financing gives the Bangladeshi Islamic banks higher Islamic bank rent opportunity.

Perception was positively associated with a Muslim account holder's decision to patronize Islamic banking products.

There are differences in the level of risk perception across funding modes. Also Islamic banks use extensively the traditional tools in mitigating risk.

The results show that analysts are not able tomake any value relevant recommendations for shariah-compliant firms, no significant value in analysts' sell recommendations for nonshariah-complaint firms.

Tunisian customers are willing to adopt Islamic insurance services.

Herfindahl-Hirschman index, both markets are low concentrated, while according to the concentration ratios, the Islamic market is considered as moderately concentrated. 
2014, Khoutem: JIABR

2014, Salihin,
Fatima \& Ousama:
JIABR

2014, Taktak, Zouari: JIABR

2014, Mokni \& Rachdi: AFE

2014, Zouari \& Taktak: IJIMEFM

2014, Ullah: IJIMEFM

2014, Lahrech, Lahrech \& Boulaksil, IJIMEFM

2014, Ergec, Kaytanci: IJIMEFM

2014, Sarac \&

Zeren: AE
Tunisia, Revolution of 2011, Work reviews, Interpretivism

Malaysia, $\quad$ Qualitative
research, Interpretivism

Tunisia, Zitouna bank financial data: 2011-2011, Mapping analysis, critical orientation

MENA region, 30: Conventional banks (15) \& Islamic banks (15), Genralized method of moments \& Regression, Positivism

15 countries, 53: Islamic banks, Regression, Positivism

Bangladesh, 334: Questionnaire to selected senior excecutive, Weighted average, percentage, SD, Variance, correlation, Positivism

15 countries, 25: Global operating Islamic banks, Generalized least-squares, Positivism

Turkey, 8: Time deposit interest rates between 20022010, Granger Causality method, Positivism

Turkey, December 2001August 2013 TDR data, Maki cointegration tests with multiple breaks and frequency domain causality tests, Positivism $\begin{array}{lr}\text { "Marketable } & \text { Islamic } \\ \text { intermediation" provides easily } \\ \text { more }\end{array}$

to finance the economic development and solve the problems of poverty and unemployment.

True and Fair View Override is relevant and applicable in Islamic accounting and auditing and not contradictory to the rules of the Shari'ah.

The development of Islamic financial education to strengthen the role played by the ecosystem.

The determinants vary between Islamic and conventional banks.

Ownership is at $49 \%$, and for 41 banks from the full sample, the ultimate owner is institutional.

Shariah compliance status of the Islamic banks in Bangladesh is poor.

Enhanching transparency will prevent shadowing profit allocation practices and place investment account holders in a better position.

Time deposit interest rates are related to Islamic bank rate of returns.

Term-Deposit rates of three Particiption banks' are significantly cointegrated with those of Conventional banks. 
2014, Sun, Hassan \& Mohamed: AFE

2014, Echchabi \& Aziz: QRFM

2014, Bekri, Kim \& Rachev: IJIMEFM

2014, Abdou, Alam \& Mulkeen: IJIMEFM

2014, Grassa \&

Matoussi: IJIMEFM

2015, Grassa: JFRC

2015, Abdallah, Hassan \& Mc

Clelland: JMFM

2015, Abdullah \& Rahman: IJIMEFM

2015, Jawadi, Jawadi \& Cheffou: AE
13 countries, 1997-2010 data period of profit margins/ net interest, Model to gaps and NIMs \& Integrated model of the net interest margin, Positivism

Malaysia, 10: well-educated \& articulate individuals Qualitative approach \& phenomenological techniques , Interpretivism

Dow Jones Islamic \& Standard and Poor's sharia index, ARMA GARCH, Positivism

UK, 487: 336 accepted credit application 151 rejected credit application, Regression and Perception, Positivism

7 countries, Descriptive analysis

Interpretivism approach,

20 countries, Literature review, Critical orientation

6 countries, 424: Firms, Multivariate analysis \& regression, Positivism

Malaysia, Sem-structude interviews \& document analysis Interpretivism method,

77 Countries, 12000: Securities, GARCH models, Positivism
Conventional banks have better assets quality of assets and liabilities with an optimum composition of profitable assets and low-costs liabilities.

The interviewers have exposure and awareness of the current criticisms of the Shariah compliance of Islamic banks.

The framework offers an improved tool to ameliorate Islamic stock market risk exposure and to reduce the costs of Islamic risk management.

Fator affecting the decisionmaking process are monthly expenses, age \& marital status.

Differences and divergence of corporate governance structure in GCC countries and in Southeast Asia countries.

Weak and poor shariah supervisory resulted to various gaps in the current shariah supervisory practices.

Risk disclosure will vary across the Gulf Cooperation Council countries despite sociocultural and regulatory similarities.

Musyarakah mutanaqisah, ljarah thumma al-bai , ijarah rental swap use wa'dan in their product structure.

Emerging market stock markets seem to be less efficient than developed Islamic markets and nonrejection of the convetional stock market point to efficiency for the former in the long term. 
2015, Dah, Hoque \& Wang: MF

2015, Makni, Benouda \&

Delhoumi: RIBF

2015, Oseni \& Hassan: JBR

2015, Ibrahim: PBFJ

2015, Marzuki \& Worthington: IJIMEFM

2015, Narayan Narayan, Phan, Thuraisamy \& Tran: PBFJ

2015, Nazlioglu, Hammoudeh \& Gupta: AE

2015, Azmat, Skully \& Brown: PBFJ

2015, Merdad, Hassan \& Hippler III: PBFJ
United States, 50: Mutual funds , Risk adjusted, cointegration analysis, Positivism Middle East, Africa, North America, Europe \& Asia Pacific, 301: IEF with periode 1993-2013, met-frontier approach with data envelopment analysis, Positivism

6 countries, 10: prominent sharia scholars, Interview, literature Interpretivism review,

Literature Interpretivism review,

Malaysia, 127: Equity funds, Regression, Positivism

Asia-Pacific, 1353: constituent firms, First-order autocorrelation, Positivism

Europe, Asia \& USA, 19992013: DJIM, SPA500, SPEU \& SPAS50TR, Hafner \& Herwartz causality-in-variance test, Positivism

Malaysia, 458 issues bond from 83 issuers, Regression, Positivism

Saudi Arabia, January 2003April 2011: Storck returns, Cross-section, Nondiversifiable risk factor, Positivism
No apparent opportunity cost for Shariah compatible investment.

The average efficiency scores during recession periods are higher than the corresponding scores during growth periods.

Extracontractual disputes or postdefault processes could avoid being caught unawares when an issue eventually crops up.

Economic stability, financial inclusion, economic development and stabilization policies are needed.

Islamic fund investors respond to performance in much the same way as conventional fund investors, increasing fund flows to better performing funds and decreasing fund flows to poore performing funds.

Market risk factors explain all momentum profits, suggesting that profits are compensation for risk.

Islamic equity market responds to shocks from the risk factors and not from oil price and the US economic policy uncertainty index during borh periods.

Conventional firm characteristics such as debt and size likewise drive Islamic credit ratings. Islamic bond characteristics such as the type of religious advisor, the regulatory changes by the AAOIFI and the bond issuer's industry also influence their ratings.

There is a negative relationship between Saudi Islamic firms and average stock returns. 
2015, Charfeddine, Najah \& Teulon: RIBF

2015, Erragraguy \& Revelli: FRL

2015, Dewandaru, Bacha, Masih \& Masih: JMFM

2015, Charles, Darne \& Pop: RIBF

2015, Ahmadvand, Dezfuli \&

Sadehvand: QRFM

2015, Khederi, Charfeddine \& Youssef: RIBF

2015, Bukair \& Rahman: IJIMEFM

2015, Omar \& Jones: IJIMEFM

2015, Sufian \& Kamarudin: IJIMEFM

2015, Hassanat \& tarawneh: JIABR
USA, March 2004-March 2011: Daily frequency data, Empirical method, Interpretivism

270: Firm , Panel-Regression, Positivism

10 countries, Daily stock indices of Islamic and conventional , Multi-scalces analysis, Positivism

USA, 14 years of daily data, GARCH models, Positivism

Iran, Library method \& TOPSIS approach, Poststructurialism

6 countries, 62: 44 conventional banks \& 18 Islamic banks , Logistic regression, Positivism

6 countries, 40: Islamic banks , Generalized least-squares, Positivism

Collection data analysis, critical thinking, Critical orientation

3 countries, 6: Financial data from 2006-2011, DEA, t-test \& OLS, Positivism

Jordan, survey of the mood: 430 persons, Positivism
Ethical investment has inferior performance compared with their unscreence benchmark.

No adverse effects on returns due to the application of Islamic and Environmental Social Governance screening: substantially higher performance results from the inclusion of good governance criteria in the post-subprime crisisperiod.

The timescales are not statistically significant.

The Islamic indexes seem to be more risky than their conventional counterparts as well as exhibit a higher performance on the full period. Method combining Murabaha and Wa'ad is the most proper strategy in Iranian stock mrket.

Islamic banks are on average, more profitable, more liquid, better capitalized and have lower credit risk than conventional banks.

Size and composition of the board have negative effect on bank performance.

Islamic FOREX products are not different.

Level of revenue efficiency on the domestic Islamic banks is higher than foreign Islamic bank counterparts.

although the proposed product is still at an exploratory stage and not a definitive product acceptable to all Muslim society, it could be a successful Islamic financial product, 
2015, Ismail,

Kamarudin \&

Sarman: JIABR

2015, Asadov, Sori, Ramadilli, Anwer \& Shamsudheen: JIABR

2015, Mroueh \& Waal: JIABR

2015, Abbas \&

Shirazi: JIABR

2015, Majid \& Kassim: JIABR

2015, Farooq \& AbdelBari: JIABR

2015, Clarke: JIABR

2015, Saqib, Zafar, Khan, Roberts \& Zafar: JIABR

2015, Yusof, Usman, Mahfudz \& Arif: JIABR

2015, Ehsan, Hasan \& Bhatti: JIABR
Malaysia, Panel data (508

companies): $\quad 3048$

observations, Cross-sectional

Dechow \& Dichev (2002) accrual quality model, Positivism

Malaysia, Interviews, Interpretivism

UAE, High Performance Organization \& Evaluation analysis, Interpretivism

Pakistan,

Micro-

entrepreneurs: 270,

Regression, Positivism

Post-1997

Malaysia,

moil, ARDL, EConomic turmoll,
VECM \& VDCS, Positivism

MENA region, periode 20052009, Regression, Positivism

UK, Islamic funds, Critical analysis, critical orientation

Pakistan, Zarai Taraqiati Bank (Muslim farmers), Good Loan analysis, Positivism

Malaysia, ARDL, IRFs \& FEVD, Positivism

Pakistan Positivism
Shariah-compliant companies have significantly higher earnings quality compared to other firms.

Islamic financial institutions consider, revaluation of property's value to its fair value especially during termination of MM contract and annual or agreed periodic review of the market value of the assets to determine the 'rental' payments by the customer.

Takaful companies in the UAE have to meet the highest international

performance standards and sustain their high levels of performance.

Islamic banks do not encourage lower-income microentrepreneurs.

IBFIs in Malaysia has significant role in Malaysian economic

Shariah-compliant firms engage in lower earnings management than non-Shariah-compliant firms.

Major inconsistencies are highlighted after analysis of the quantitative screens.

Riba-free financing is essentially needed by poor Muslim farmers who, owing to prohibition of Riba, do not rely on interest (Riba)-based financing.

Macroeconomic shocks have different long-run and short-run effects on amount of home financing offered by conventional and Islamic banks.

Gender, income, and marital tatus wield some influence on this decision but demographic factors do not affect the decision. 
2015, Grais \& Rajhi: JIABR

2015, Rosman \& Rahman: JIABR

2015, Senadjki \& Sulaiman: JIABR

2015, DIAW: JIABR

2015, Bilal \& Meera: IJIMEFM

2015, Andrew \& Worthington: IJIMEFM

2015, Miah \& Sharmeen: IJIMEFM

2015, Basov \&

Bhaatii: JIFMIM

2015, Shahari, Zakaria \& Rahman: IJMF

2015, Maali \& Atmeh: IJIMEFM

2015, Bahrini: IJIMEFM

Malaysia \& Bahrain,
Examination of existing
literature, Interpretivism

Universal, Non-parametric test, Positivism

Malaysia, Households: 102, One-way ANOVA, Positivism

Universal, Literatur review \& critical analysis, critical orientation

Malaysia, Descriptive research method, Poststructurialism

Libya, 385: Libyan retail consumers , Descriptive, factor \& discriminant analyses, Positivism

Bangladesh, 10: Audited financial statement from period 2001-2011, Regression, Positivism

Literature and model review, Interpretivism

11 countries, 40: Islamic banks, VAR on Panel data, Positivism

Critical thinking, Critical orientation

MENA countries, 33: Islamic banks operating during period 2006-2011, Panel data models used to investigate the determinants of TFP change, Positivism
In a crisis monetary policy and systemic liquidity management will be at the forefront of the stabilization efforts.

A lack of effective risk management practices was found in relation to liquidity risk, displaced commercial risk and equity investment risk by Islamic banks.

Poverty can be fought with commitment, faith and guided principles based on faith.

Most of the authors reviewed acknowledged the technical mistakes put forth by many conventional analysts as causes of the crisis. However, they have showed that the adoption of the principles of Islamic finance would have prevented most of those mistakes.

Practice of credit card in Malaysia is still controversial.

Resondents have at least some knowledge about some Islamic products.

Conventional banks are more efficient in managing cost than Islamic banks.

Small disadvantage of Islamic banks may have comparatively to the conventional ones can be severely exacerbated by positive assortive matching.

Majority of Islamic banks use debt-based financing and avoid asset-based financing.

Islamic banks are increasingly using concept of the Takaful \& Tabarru.

GCC banks have known a productivity decline between 2006-2011. The productivity growth of MENA Islamic banks was mainly determined by bankspecific factors. 
2015, Gilani:

IJIMEFM

2015, Azmat, Skully

\& Brown: PBFJ

2015, Daher, Masih \& Ibrahim: JIFMIM

2015, Mollah \&

Zaman: JBF

2015, Ayedh \&

Echchabi: QRFM

2015, Olorogun: IJIMEFM

2015, Htay, Sadzali

\& Amin: QRFM

2016, Boulanouar \& Alqahtani: IJIMEFM

2016, Zarrouk, Jedidia \& Moualhi: IJIMEFM

2016, Nasser, Hikmany \& Oseni: IJIMEFM

2016, Yusof, Mahfudz, Arif \& Hayati: IJIMEFM
Explanatory and descriptive in nature, Interpretivism

Literature Review \& Model debt financing firm, Interpretivism

18 countries, 128: Conventional \& Islamic banks, Two-step dynamic generalized method of moment, Positivism

25 countries, 164: Islamic banks, Regression, Positivism

Yemen, 9: Interviewers , Qualitative approach, Interpretivism

$\begin{array}{ll}\text { Malaysia, } & \text { Mathematical } \\ \text { derivative } & \text { procedures, } \\ \text { Interpretivism } & \end{array}$

Malaysia, 200: Malaysian lower income group, Qualitative approach, Interpretivism

Saudi Arabia, 33: Insurance companies, IR \& AIR, Positivism

MENA countries, 51: Islamic banks from 1994-2012, System-generalized method, Positivism

Tanzania, Comparative study, Interpretivism

Malaysia, Financial simulation , Poststructurialism
The involvement of ethics in different procedures, operations and approaches of Islamic banking and how it is perceived by its many stakeholders.

The model is augmented with risk averse depositors to show that the emergence of asset side could be deterred by Islamic banks' liability side.

Privately owned Islamic banks attempt to safeguard shareholders by independently mitigating the effects of displaced comemercial risk through higher capital buffers.

Shariah supervision boards positively impact on Islamic banks performance when they perform a supervisory role.

The Islamic banking still lacks regulations and standards.

The derivation of underwritting returns through convolution of accumulated funds and claims paid views in the form insurance industry.

The lower income people are willing to contribute about RM5 per month.

Underpricing not only exist but also is among the highest in the world.

Profitability is affected by banks' cost-effectiveness, asset quality and level of capitalization.

Court system provides main avenue for Islamic finance litigation.

Proposed rate rental-index is found to be more stable, having less fluctuation, resilent to macroeconomic and comparable to the conventional interest rates. 
2016, Ahmed:

IJIMEFM

2016, Moshin: IJIMEFM

2016, Khir: IJIMEFM

2016, Khasawneh: IJIMEFM

2016, Louati, Louhichi \&

Boujelbene: MF

2016, Gimigliano: IJIMEFM

2016, Ergec, Kaytanci \& Toprak: IJIMEFM

2016, Ahmed, Sabirzyanov \& Rosman: JIABR

2016, Gharbi \& Khamoussi: JIABR

2016, Narayan \& Phan: PBFJ
Pakistan, 370: Administrated stakeholders, Content analysis, Positivism

Malaysia, Data collected analysis , Critical orientation

Deductive \&Inductive, Critical orientation

MENA countries, , Descriptive \& analytical approach, Interpretivism

MENA countries, 34 Islamic banks \& 89 Conventiona banks, Triple square model, NPL ratio, z-score, Positivism

Italy,Laws \& regulation analysis, Interpretivism

Turkey, 500: bank customers, Semi-structured survey, Positivism

Malaysia, Study review, Critical analysis

GCC, CBs: 40 lbs: 20 from 2003-2011, Regression, Positivism

United States, 532: Islamic stocks, Regression, Positivism
Islamic banks are not well stating their missions statements.

Potential of cash waqf in financing not only religious areas but also financing different goods and services needed.

Bilateral rebate instead of unilateral rebate to be the best and fairnest Islamic mechanism to overcome injustice in several events that may be impact the banks liquidity.

Determinants of banks profitability and stability are different according to bank's type.

The best capitalized western banks more engaged in the excessive risk-taking behavior, resulting in increased toxic-loan ratios and simultaneously a rather shaken stability.

No sharia-compliant institution has been authorised yet, but no legal obstacle is laid down.

Religiousity is not the most significant and leading factor in Islamic bank preference.

IFRS-based financial reporting primarily focuses on economic consequences of financial instruments, AAOIFI further takes into consideration the legal structure of the instruments, which are based on Shari'ah precepts.

Empirical evidence shows that there is a significant change in dynamic volatility in GCC banking sector because of financial crisis 2008.

The market risk factors namely excess market returns, value, size and betting againts beta factors and macroeconomic risk factor. 
2016, Balcilar, Cerci \& Demirer, MF

2016, Chen \& Ngo: GFJ

2016, Bousalam \& Hamzaoui: JFRC

2016, Boo, Ee, Li \& Rashid: PBFJ

2016, Aloui, Hkri, Lau \& Yarovaya: FRL

2016, Ismail, Ghani

\& Zain: IJIMEFM

2016, Kabir \&

Manahov: FMII

2016, Naifar, Hammoudeh \& Dohaiman: JIFMIM

2016, Maghyereh \& Awartani: RIBF

2016, Narayan, Phan. Sharma \& Westerlund: PBFJ

2016, Mensi, Hammoudeh, Sensoy \& Yoon

2016, Mehdi \& Mghaieth: RIBF
United States, 468: weekly closing price, GARCH models, Positivism

United States, 1091: Index over 1999-2011, Panel data Debt ratio analysis, Positivism

Morocco, 36: month average market value equity, $\mathrm{ARCH}-$ EGARCH, Positivism

Malaysia, 448: 131 Islamic mutual funds 317 conventional mutual funds, Modified Value at Risk (MVaR), Positivism

USA, 20: Equity indexes from period 1990-2010, Squared wavelet coherence, Positivism

Malaysia, Review on the underlying contracts, Poststructurialism

4 countries, 10: Daily price observation, VAR-VECM, Positivism

3 countries, Data set of daily yield-to-maturity series for sukuk, Daily returns stock market SPAS50 for conventional global market, Archimedean copulas, Positivism

US, 10: Years financial history, VAR, Positivism

3 countries, 2577: Islamic stocks, Robustness test, Positivism

10: Dow Jones Islamic \&conventional sector index pairs, GARCH models, Positivism

USA, 200-2014, GARCH Model (DCC-FIAPARCH), Positivism
Low degree of association between Islamic bonds and global stock markets with episode of negative correltions observed, particularly during market crisis periods.

An increase in debt level bear a more severe decrease in liquidity and institutional ownership.

Screening process resulted in well-diversified universe of Shariah-compliant stocks to invest in.

Islamic mutual funds generally outperformed conventional funds in the riskiest asset class, equity, one year before and during the global financial crisis.

Time-varying nature of comovement exists for both the Islamic and conventional indexes.

Deposit taking activities are characterized by principal guaranteed.

US Islamic equity index is the leader among three independent indices.

The finding indicates that some characteristics of Islamic are similar to those conventional bonds. Second issue, sukuk behavior is different from those conventional bonds.

Sukuk is important in the strategic asset allocation and hedging of portfolio fund mangers.

Eevidence of predictability only when US stock returns are used as a predictor.

Significant time-varying conditional correlations for all pairs.

The DCC-FIAPARCH is the best model for conditional heterosedsticity. 
2016, Fakhfeh, Hachicha, Ghorbel \& Selmi: JAM

2016,

Wasiuzzaman: JAM

2016, Saakti, Tareq

\& Mahdzir: QRFM

2016, Chatta \&

Archer: JIABR

2016, Grassa: JIABR

2016, Naim, Long, Bakar \& Hussain: JIABR

2016, Shafii \& Rahman: JIABR

2016, Gungdogdu: JIABR
USA, January 1, 1996- March 17, 2014 daily data, FIEGARCH-EVT, Positivism

Saudi Arabia, 9 years trading volume, ARMA GARCH, Positivism

Malaysia \& Singapore, Phenommenological techniques data analysis, Interpretivism

UK, Cbs \& ICBs, Two-stage process, Positivism

GCC, Ibs: 43 during 20052012, Three-stage least square, Positivism

Universal, content analysis, interviews, observations and descriptive analysis using figh muqaran, Interpretivism

Universal, study of documents and textual analysis of Shariah opinions of scholars and relevant accounting standards, Interpretivism

Universal, Critical realism, Critical orientation
The dependence structure proves to differ noticeably among the Islamic Dow Jones- oil price aand the conventional Dow Jones one. The returns are lower and volatility is higher during the hajj period.

Shariah scholars are aware of the Shariah issues surrounding Islamic derivatives.

The sensitivity of the CAR of an ICB with respect to the changes in the values of alpha and the proportion of unrestricted PSIA on the funding side.

Income structure influences the insolvency risk in Islamic banks with a concentrated ownership structure.

Shifting the burden of proof to the fiduciary is the weightier view and necessary to ensure that both sides are protected.

Classification and measurement of equity-based Islamic financial assets do not fit into the "default" classification category of amortised cost, as the future cash flow receivable does not constitute solely the payment of principal and interest (fixed rate payment).

Export Credit Agency export financing structures, or restricted Mudaraba if preferred, with an embedded supplier financing Wakala agreement can pave the way for Islamic Fls to support exporting companies. It is also concluded that development and support of the Takaful industry are vital for the success 
2016, Azmi, Aziz, Non \& Muhamad: JIABR

2016, Farooq \& Alahkam: JIABR

2016, Gharbi: JIABR

2016, Saqib, Farooq \& Zafar: JIABR

2016, Ghosh: JIABR

2016, Hardianto \& Wulandari: IJIMEFM

2016, Wulandari, Putri, Kassim \& Sulung, IJIMEFM

2016, Ashraf, Rizwan \& L'Huillier: JFS
Malaysia, Expert from differenct companies: 13, structured

interviews with individuals involved in the preparation of annual reports of Shariacompliant, Interpretivism

MENA, Ibs: Periode 20052009, Pooled Least Square, Positivism

Tunisia, Inductive methodology \& Qualitativenarrative Interpretivism

Pakistan, Account holders of Ibs: 242, SERVQUAL model, Positivism

GCC countries, Islamic banks in GCC countries: 1996-2010, Dynamic panel data, Positivism

Indonesia, 39: conventionl banks (31) \& Islamic banks (8), Stochastic frontier approach and panel data regression, Positivism

Indonesia, 32: bankers from 14 Islamic banks, Forum group discussion, literature review, Interpretivism

136: Islamic banks from 30 jurisprudentions, Pairwise correlatiion matrix, Positivism
Sharia-compliant companies and professional users interviewed agree that the most relevant Sharia-related information is most commonly understood as the information found in the financial statement and its notes (accounting-related disclosures).

shariah-compliant firms underperform non-shariahcompliant firms.

the use of reference rate obtained in non-Islamic financial system is inappropriate from the Islamic perspective, the authors suggest nominal gross domestic product (NGDP) growth rate as an alternative benchmark because Islamic finance, in its ideal sense, is based on and closely linked to the real sector.

Significant moderating effects of Shari'ah compliance perception on the relation between service quality and customer satisfaction have been identified. The findings appear to suggest that although Macro Prudential Policies are useful, not all of them are equally effective in containing the potential build-up of financial stress.

Islamic banks have a higher intermediation ratio, proportion on fee income-to-total operating income and are less efficient.

Fairness to customer, country regulation, perceived business practicality and product characteristic affecting the contract agreement.

Modified net stable funding ration has positive impact on the financial stability of Islamic banks. 
2016, Soedarmono, Pramono \& Tarazi: RIBF

2016, Alqahtani, Mayes \& Brown: PBFJ

2016, Bekele, Chowdhury \& Rao: RBF

2016, Wanke, Azad, Barros \& Hassan: JIFMIM

2016, Abdullah: IJIMEFM

2016, Kassi: GFJ

2016, Hanif: IJIMEFM

2016, Abozaid: IJIMEFM

2016, Ahmed \& Salleh: IJIMEFM

2016, Yungucu \& Saiti: QRFM
1997-2012: Islamic bank around the world, Regression Model, Positivism

GCC countries, 101: Banks , CAMEL indicators

UAE, 4799: individual borrowers, Box-Cx double hurdle model, Positivism

16 countries, 114: Islamic banks, Data Envelopment Analysis (DEA) \& TOPSIS, Positivism

United States, Qualitative document and content analysis, Interpretivism

Malaysia, Quaterly data for the period 1998-2013, ARDL, Positivism

Literature \& Legal review, Interpretivism

Literature review \& descriptive analysis, Interpretivism

IFP Framework, Interpretivism

Past study Poststructurialism
Loan loss provisioning in Islamic banks remains procyclical.

The Islamic banks performed better in terms of capitalisation, profitability and liquidity in the early stage of the global financal crisis, they performed worse in later stages with the real economic downturn.

The profitability of default are not different between Islamic \& conventional banking borrowers.

Variables related to both country and cost structure have a prominent impact on efficiency. The Islamic banking market would benefit from higher level of competition between institution.

Assessing economic substance over legal form, each of the three products involved riks-free transaction and interes.

Islamic finance has started to make important contributions to the real economy.

Process that legally contracts/products are line with theory.

Islamic banking and finance facing some internal challenges.

The complementary role of the non-poor households who provide funds for zakat and waqf.

Majority of these study have documented the negative effects. 
Table 4.

Empirical research papers in Islamic banking and finance (After 2017)

\begin{tabular}{|c|c|}
\hline Yr/Author:Journal & $\begin{array}{c}\text { Country, Sample, Method, } \\
\text { Paradigm }\end{array}$ \\
\hline $\begin{array}{l}\text { 2017, Azmi, Non \& } \\
\text { Aziz: IJMEFM }\end{array}$ & $\begin{array}{l}3 \text { countries, 19: Shariah } \\
\text { screener \& advisors, In-depth } \\
\text { intervirew, semi-structured, } \\
\text { Positivism }\end{array}$ \\
\hline $\begin{array}{l}\text { 2017, Darus, Shukri, } \\
\text { Yusoff, Ramli, Zain \& } \\
\text { Bakar: RIBF }\end{array}$ & $\begin{array}{l}\text { Malaysia, } 16 \text { Islamic bank \& } 8 \\
\text { Takaful organizations, CSR } \\
\text { index, Positivism }\end{array}$ \\
\hline $\begin{array}{l}\text { 2017, Alandejani \& } \\
\text { Asutay: RIBF }\end{array}$ & $\begin{array}{l}\text { GCC countries, 2005-2011: } \\
\text { Financial statement, } \\
\text { Generalized method of } \\
\text { moment, Positivism }\end{array}$ \\
\hline
\end{tabular}

2017, Leon \& Weill: PBFJ

53 countries, 15309: Firms, Correlation \& regression, Positivism

2017, Rashid, Yousaf

Pakistan, 20: 10 conventional banks, 4 full-fledge Islamic \& Khaleequzzaman: banks \& 6 Islamic branchs IJIMEFM

from 2006-2012, Z-score \& Regression analysis, Positivism

Pakistan, 10: Annual reports 2017, Sheikh \& from 2004-2014, Ordinary Qureshi: IJIMEFM \& least square regression \& fixed effect and random effect, Positivism

Pakistan, 15 Sukuk and 30

2017, Nasir \& Farooq: Term Finance Certificates, JIABR

Delta normal approach, Positivism

2017, Oladapo \& Nigeria, Muslim from Nigeria: Rahman: JIABR 212 (Male) \& 172 (Female), Positivism

2017, Ahroum \& Gordon \& Shapiro model, Achchab: JIABR Interpretivism

\section{Findings}

Companies still make Islamicrelated disclosures on a voluntary basis.

Corporate waqfis viewed as a viable alternative to help address social issues of the community.

Sectoral distribution of Islamic financing has an adverse impact on NPL.

Islamic banking development has no impact on credit constraints, while conventional banking development alleviate obstacle to financing.

Income diversity, profitability ratio, loan to asset ration, asset size and the market concentration ratio of banks have significant effects on the stability of banks.

Islamic commercial banks have relatively more fixed operatig assets and growth in total assets.

Results revealed that Sukuk are less risky and more stable instrument as compared to conventional bonds.

Individual factors such social justice and human rights have effects on the factors of human development.

Negotiating only the profit and loss sharing ratio is not sufficient to

have a fair price of Sukuk Musharakah when the underlying is a joint venture. 
2017, Afou: JIABR

2017, Baki \& Uthman: JIABR

2017, Zarrouk, E Ghak \& Haija: JIABR

2017, Fakhfakh: JIABR

2017, Megeid: JIABR

2017, Alswaidan, Daynes \& Pasgas: JIABR

2017, Mukhlisin: JIABR

2017, Atmeh \& Maali: JIABR
Tunisia, Organizations \& audit firms: 200, questionnaire survey based on the relevant literature, Positivism

Dialectic analysis, Positivism

UAE, Time series data: 19902012, Non-parametric approach, Positivism

Bahrain, Bangladesh, Britain, Malaysia,

Pakistan, Kingdom of Saudi Arabia, the Republic of the Sudan, Tunisia, Palestine, Jordan

and Oman, 27 Auditing reports: 2012-2013, Comparative examination, Positivism

Egypt, CBs \& Ibs: 2004-2011, analyzing the financial statements, Positivism

UK, Meta-analysis,
Interpretivism

Indonesia, Meta analysis in IFRS issued 2005-2012, Interpretivism

Jordan, Review analysis, Interpretivism
Tunisian practitioners are not well aware of most of the AAOIFI standards'.

Islamic banks' performance in terms of their social ideals is misplaced, as the environment in which they currently operate does not support such goals.

direction of causality runs from financial development to economic growth and the reverse causality does not drive this relationship; however, the real gross domestic product (GDP) causes Islamic financial development with no reverse effect.

lack of harmonization in several elements related to the form of the auditor's report and in all elements related to the content of the auditor's report among the Islamic banks.

Egypt, CBs perform better in terms of liquidity risk management than IBs.

Sukuk risk profiles are directly related to Sukuk structures.

literature emphasis not only on the technical matters related to financial

reporting standardization but also on the complex arrangement in different country settings.

in some products, the economic substance is presented in the financial reports, while in other cases, the legal form of the contract is reported. 

2017, Sherif \& Erkol: 2015 \& 2000-2017, Event JIABR

study

Positivism

Malaysia, Mathematical model, Positivism

2017, Shaikh: JIABR

2017, Nawaz Haniffa: JIABR

2017, Ahmed, Nawaz, Danish, usman \& Shaukat: JIABR

2017, Rafay, Sadiq \& Ajmal: JIABR

2017, Albassam \& Ntim: JIABR

2017, Lusyana Sherif: JABR

2017, Hummel \& Goud: JIABR
UK, period 2007-2011, VAIC, Positivism

Pakistan, Customers: 370, content analysis, Positivism

Pakistan, Sunni madhaib: 4, Descriptive \& Explanatory, Interpretivism

Saudi, Saudi-Listed firms: 75 , Multivariate regression, Positivism

Indonesia, Jakarta Index: -30 \& to 60 after $60+$ days, Event study Positivism methodology,

US, Ponamo Beach (Florida), Islamic financing approach to test for competitiveness to a conventional approach, Positivism
Only insignificant difference in reaction to Sukuk and conventional bond issuances for the overall period and pre-crisis period.

Debt finance requires frequent repayments and indebtedness for financial inclusion. Conversely, the Islamic equity modes of financing in their current baseline structure suffer from high agency costs.

Positive relationship between Value Added Intellectual Coefficient and accounting performancebased on return on assets (ROA).

mission statements of Islamic banks working in Pakistan are not good at communicating the corporate goals clearly Model acceptable to all madhahib of Islamic Figh.

corporations that depict greater commitment towards incorporating

Islamic values into their operations through high Islamic values disclosure index score engage in higher voluntary $C G$ disclosures than those that are not.

inclusion of the ISSI has a positive impact on the financial performance of the included shares during the 41-day event window.

When incorporating a crowdsourced option along with an ijara and esham approach, the returns on investment are higher than for a conventional approach. 


\section{7, Uddin, Bangladesh, 25: 18 Chowdhury \& Islam: Conventional banks 7 Islamic IJIMEFM \\ 2017, Korbi, Bougatef: IJIMEFM \\ 2017, Mili \& Abid: IJIMEFM banks, Dynamic GMM \& Quatile Regression, Positivism \\ 17 countries , 224: 68 Islamic banks 156 conventional banks, Z-Score, Positivism \\ Explanatory factor Poststructurialism credit risk, capital adequacy ratio and efficiency ratio of conventiona banks and Islamic banks differ at different percentile. \\ Islamic banks seem to be less stable than their conventional peers. \\ Franchise value is an important determinant of Islamic bank risk-taking.}

2017, IJIMEFM Alharbi:

OIC countries, 110: Islamic Unbalanced data fixed-effect regression model, Positivism

Pakistan, 24: conventional 2017, Khan, Khan \& Tahir: IJIMEFM

2017 Suandi: IJIMEFM

2017, Cupian Abduh: IJIMEFM

2017, Kayed: IJIMEFM

2017, Mbawun Nimako: IJIMEFM

$\&$ PLS-SEM, Positivism

Indonesia, 27: Islamic banks, Concentration ratio and Herfindal-Hirschman index \& Panzar-Rosse-H statistics and Lerner index, Positivism

Saudi Arabia,

12: Profitability, lagged dividends and Conventional banks Islamic banks (6), PanelRegression, Positivism

2017, Oseni Omoola: JFRC

$\&$

Malaysia, 109: respondent in Malaysia, Multivariate sttistical anlysis, Positivism

2017, Islam \& Indian, 290: Indian Muslim, Rahman: IJIMEFM Statistical analysis, Positivism
The statistical significance level of

Capital ratio, other operating income, GDP per capita, bank size, concentration and oil prices affected Islamic bank positively.

Islamic banks are relatively better in profitability, efficiency, risk and liquidity management.

The result show heterogeneity of classification for Profit Sharing Investment Accounts.

The least influental factors were perceived religion effect (PRE) and perceived threat of violence (PVT).

Islamic banking industry in Indonesia operating in a higher degree of market power which leads to a less competitive market.

leverage are all significant determinants of Islamic banks' dividend policy.

"Acces to justice and "resolving disputes" are the most ifluencing factors affecting the intention use ODR among stakeholders.

Majority of the respondents lack an understanding of how Islamic banking works. 
2017, Shibani \& Comparative and analytical Fuentes: RIBF methods, Interpretivism

MENA, 129: Islamic (41) \&

2017, Mahdi \& conventional (88) banks, Abbes: RIBF

2017, Nawaz: TIJBS

2017, Narayan Phan: PBFJ

2017, Farag, Mallin \& Yong: JIFMIM

2017, Othman

2017, Majid, Falahaty \& Jusoh: RIBF

2017, Wei \& Thaker: QRFM

2017, Baber: QRFM Fishburn's risk measure and Kendall's t, Positivism

174: Banks, Regression, Positivism

Review, Poststructurialism

13 countries, 90: Islamic banks, Positivism

10: Islamic banks, Multivariate discriminant analysis (MDA), Positivism

MENA countries, 130: Islamic 2017, Mahdi \& and conventional banks, Abbes: RIBF

2017, Bitar, Hassan \& Walker: JFS Simultaneous equation model , Positivism

Turkey, 40: banks, Factor extracted from principal component analysis, Positivism

50: 36 conventional and 14 Islamic banks, Stochastic frontier \& Meta-frontier Approach, Positivism

Malaysia, 8: Scholars \& bankers in Islamic banking, Qualitative research approach, Interpretivism

Extensive literature reviews, Critical orientation
Islamic governance demonstrate that mainstream corporate governance is not a law of nature but a social construct.

Bank above the target level tend to show risk aversion behavior, while the banks listed below tend to be risk-oriented.

Quality and size of the advisory board to have the opposite effect on market value.

Focus on new areas and quality of research.

The larger the ShariahSupervisory Board (SSB) the better the financial performance.

Predictive ability of the integrated model to differentiate healthy and non-healthy Islamic banks, thus reducing the expected cost of bank failure.

\section{Positive bidirectional} relationship between capital and risk of Islamic banks.

Challenges Islamic banks face in western countries in terms of perception, financial infrastructure, and regulatory constraints.

Factors in efficiency between the two banks are the wide disparity from their respective best banks and technological constrains.

The Islamic banking and finance is developing in line with its counterpart-the conventional banks.

The Bai bithaman ajil is a convergence of conventional housing finance and does not fall in line wih Shariah regulations. 
2017, Rehman, Pakistan, 150: bank senior Benamraoul \& Dad: mangers, In-depth interview JAM

2017, Othman, Majid \& Rahman: PBFJ

2017, Rejeb: RIBF

2017, Narayan, Phan, Narayan $\&$ Bannigidadmath: PBFJ

2017, Karabiyik, Narayan, Phan \& Weserlund: PBFJ

2017, Mahdzan, Zainudin, Hashim \& Sulaiman: IJIMEFM

2017, Hammami \& Oueslati: JIFMIM

2017, Ariff, Chazi, Shafari \& Zarei, JEMF

2017, Hikiri, Hammoudeh, Aloui \& Yarovaya: PBFJ

2017, Mwamba, Hammoudeh \& Gupta: PBFJ

2017, Mbengue: RIBF

2017, Trabelsi Naifar: RIBF analysis, Positivism

Malaysia \& Indonesia, 26: 17 Malaysian 9 Indonesian banks,Frontier approach, Positivism

\section{GARCH models, Positivism}

US, Europe, Australia, Asia, 2000: stocks listed on multiple markets, Regression, Positivism

19 countries, 900: Islamic stocks, Vector Error Correction Model (VECM), Positivism

Malaysia, 751: Muslim working individuals, Probit regression model, Positivism

GCC countries, 157: Mutual funds, methodology, Positivism

Malaysia, 9: montly treasury bills, treasury bonds, government agency bonds \& AAA-rates bonds, ARDL-ECM, Positivism

4 countries and 2 zone areas, 12: Islamic \& conventional indexes, VAR, Positivism

US, Europe, Asia, 4: Market indexes, VAR, Positivism

West Africa, 3: BRVM, GSE, NSE, $S$ \& $P$ methodology, Positivism

US, Europe, UK \& GCC, Sample Period: 2005 to 2015, GARCH models, Positivism
Risk identificaation, risk assessment and analysis, credit risk analysis and risk governance are efficient in explaining the risk management practices of Islamic banks.

Bank with partnership financing are more efficient than other banks.

Islamic stock markets are not immune to the global financial crisis.

High and low news sensitive stocks generates additional profit of $5,60 \%$ per year.

A mean variance investor makes annualized average profit of $4,91 \%$ compared to an average buy-and-hold profit of 2,97\% per annum.

Islamic religiosity is insignificantly related to portfolio allocation.

Skilled managers exist in the Islamic mutual fund industry.

The average of sukuk treasury bonds are higher than conventional treasury bonds.

Global financial crisis strongly affect the cross-market volatility.

During major crisis the islamic stock index is not less risky but also significantly different from conventional stock market.

Financial sector reducing number of securities.

Systemic risk has adverse effect on Islamic indexes, with a lower level in GCC Countries. 
2017, Derbali, Khaldi \& Jouini: JAM

2017, Alam, Akbar, Shahriar \& Elahi: QRFM

Descriptive Interpretivism

Malaysia, 10: sharia publiclisted companies, CAPM regression, Positivism

2017, Sakti, Tareq, Theoretical \& Empirical Saiti \& Akhtar: QRFM review, Positivism

MENA, 13: Annual data from period 2000-2013,

2017, Sherif \& Multivariate Hussnain: IJIMEFM

2017, Akhter, Pappas \& Khan: RIBF bootstrapping generalised Positivism analysis, and method,

ASEAN \& Middle East, 14: Countries, Panel Regression, Positivism
Islamic CAPM is applicable in investigating the linkage among risk and return in the Islamic stock market.

Revisiting the norms laid down by Shariah and current global practices of Islamic stock market and indexes.

Literature on IB capital structure is largerly theoretical than empirical.

Demand for family Takaful in MENA are affected by inflation, financial development and male life expectation.

Islamic and conventional insurance demand to be negatively affected by GDP/ capita, albeit the Islamic showing a greter resilence during crisis. 
292 Do You Capture Financial Crisis?

This page is intentionally left blank 